дошкільних навчальних закладів із зазначеними категоріями сімей, адаптації дітей із порушеннями розвитку до умов ДНЗ та можливостей їхнього подальшого навчання у закладах освіти.

\title{
Література
}

1. Алєксєєнко Т. Готовність батьків до виховання дитини / Т. Алєксєєнко // Педагогіка i психологія. - 2002. - № 4. - С. 37-46. 2. Вавіна Л. Створення інноваційного навчально-виховного середовища як головна умова комплексної реабілітації дітей з розладами зору / Л. Вавіна // Дефектологія. - 2001. - № 4. - С. 11-13. 3. Дегтяренко Т. Корекційно-реабілітаційна робота в спеціальних дошкільних закладах для дітей з особливими потребами / Т. Дегтяренко, Л. Вавіна. Суми : ВТД «Університетська книга», 2008. - 302 с. 4. Кравченко Т. «Життєві сценарії» сім'ї та їхній вплив на соціальний розвиток особистості / Т. Кравченко // Педагогіка і психологія. - 2002. № 1 - 2. - С. 61-67. 5. Макаренко І. Соціально-психологічний супровід сім'ї, яка має дитину 3 особливими потребами / I. Макаренко // Дитина - педагог: сучасний погляд. Психолого-педагогічні та соціальні аспекти сучасної дошкільної та початкової освіти : колективна монографія / авт. кол. : О. Алматьєва, Г. Бєлєнька, Н. Гавриш, В. Докучаєва, В. Желанова, Н. Курило, С. Курінна та ін.; за заг. ред. В. Докучаєвої; Держ. закл. «Луганський національний університет імені Тараса Шевченка». - Луганськ : Вид-во ДЗ «ЛНУ імені Тараса Шевченка», 2010. - С. 467-491. 6. Мальцева О. Педагогічна культура сім'ї як соціально-педагогічна проблема / О. Мальцева // Соціальна педагогіка : теорія та практика. - 2007. - № 2. - С. 54-58. 7. Пантюк Т. Основи корекційної педагогіки / Т. Пантюк, О. Невмержицька, М. Пантюк. - Дрогобич: Редакційно-видавничий відділ Дрогобицького державного педагогічного університету імені Івана Франка, 2007. - 278 с. 8. Садова I. Основи дефектології / I. Садова. - Дрогобич : Редакційно-видавничий відділ Дрогобицького державного педагогічного університету імені Івана Франка, 2011. - 230 с.

УДК 372. 21: 4

Н. П. Пихтіна,

кандидат пед. наук, доиент, Ніжинський державний університет імені Миколи Гоголя

\section{ОСОБЛИВОСТІ ПОПЕРЕДЖЕННЯ СИТУАТИВНИХ НЕГАТИВНИХ ПРОЯВІВ У ПОВЕДІНЦІ СТАРШИХ ДОШКІЛЬНИКІВ}

Пихтіна Н. П. Особливості попередження ситуативних негативних проявів у поведінці старших дошкільників.

У статті окреслено, обгрунтовано та практично вивчено особливості попередження ситуативних негативних проявів у поведінці старших дошкільників.

Ключові слова: негативні прояви у поведінці, попередження, профілактика, культура поведінки, виховні стратегії.

Пыхтина Н. П. Особенности предупреждения ситуационных негативных проявлений в поведении старших дошкольников.

В статье представлены результаты теоретического анализа и практического изучения особенностей предупреждения ситуативних негативных проявлений в поведении старших дошкольников.

Ключевые слова: негативных проявлений в поведении, предупреждение, профилактика, культура поведения, воспитательные стратегии.

Pykhtina N. P. Features of situational negative phenomena prevention in the behavior of older preschoolers.

The results of theoretical analysis and practical study of the features of situational prevention of negative phenomena in the behavior of older preschoolers

Keywords: negative developments in behavior, prevention, prevention, culture of behavior, education strategies.

Складність процесу розвитку та формування особистості, наявність чинників негативного впливу в суспільному середовищі відбивається на свідомості й поведінці 
дітей та молоді, система цінностей яких ще не знайшла достатнього становлення i зміцнення. Це зумовлює необхідність здійснення профілактичної роботи та внесення педагогічної корекції у поведінку особистості, що формується.

Профілактика девіантної поведінки особистості належить до складних педагогічних проблем, успішне розв'язання яких можливе лише на основі наукового осмислення сутності цього явища, а також урахування особливостей формування та вікового періоду, в межах якого зароджуються негативні прояви поведінки, як початковий етап у формуванні в майбутньому стійких поведінкових відхилень.

Тому головним напрямком у роботі з дітьми дошкільного та молодшого шкільного віку $\epsilon$ здійснення ранньої профілактики негативних проявів у поведінці дітей, оскільки саме вони, на думку сучасних дослідників (Т. Федорченко, О. Потапова) зароджуються та виникають у дошкільному та молодшому шкільному віці. Для дітей цих вікових категорій найбільш поширеними $є$ такі негативні прояви у їхній поведінці: істерики, агресивність, сором'язливість, замкнутість, нечесність, страхи, гіперактивність. Вони можуть зумовлюватись такими групами чинників: неправильними типами виховання в сім'ї, незабезпеченням потреби дитини в увазі і любові, кризами психовікового розвитку дитини, її несприятливою адаптацією до ДНЗ та школи.

Аналіз досліджень, присвячених вивченню проблем педагогічної занедбаності, важковиховуваності, відхилень у поведінці, що виникають і виявляються вже у старшому дошкільному та молодшому шкільному віці (В. Оржеховська, О. Потапова, Т. Федорченко), надають підстави висловити припущення, що саме попередження ситуативних негативних проявів у поведінці дітей $\epsilon$ найбільш ефективним у їх нівелюванні, запобіганні ускладнень і трансформацій у більш складні і стійкі відхилення. Тому метою написання статті є обгрунтування висунутого припущення. Це зумовлює необхідність розв'язання таких дослідницьких завдань:

1. Окреслити та проаналізувати особливості попередження ситуативних негативних проявів у поведінці дітей, а саме: формування культури поведінки дитини; оперативного реагування на ситуативні негативні прояви; педагогічно доцільної стратегії у вихованні дітей із негативними поведінковими проявами.

2. Практично перевірити названі вище особливості.

Формування культури поведінки дошкільників як превентивна основа попередження негативних проявів у їхній поведінці.

Під культурою поведінки науковці розуміють сукупність способів самоорганізації діяльності відповідно до морально-естетичних вимог суспільства шляхом зіставлення власних й естетичних інстанцій із соціальними очікуваннями оточуючих людей [7, с. 7].

Зміст такої поведінки складають: дотримання дитиною гігієнічних навичок; культура вчинків у різних ситуаціях і позитивних стосунків у різних видах діяльності; наявність конкретних елементів моральної свідомості й моральних почуттів; елементи трудових навичок.

Оскільки науковці (М. Федорова, Т. Федорченко, О. Потапова) розглядають поняття виховання культури поведінки дошкільників як послідовність позитивних кількісних $\mathrm{i}$ якісних змін у когнітивній, мотиваційній, емоційно-почуттєвій та діяльнісній сферах особистості, то недостатня сформованість вказаних показників, може розглядатись як передумова зародження і формування поведінкових відхилень.

Дослідження засвідчують, що культура поведінки найінтенсивніше формується в дітей 6-річного віку, оскільки, за оцінкою Т. Федорченко, саме цей віковий період є найбільш сенситивним для цього. У переддошкільному й молодшому шкільному віці, оцінюючи ті чи інші вчинки, діти не тільки змінюють свої моральні знання, але й усвідомлюють моральний зміст, мотиви цих вчинків.

Поняття культура поведінки дитини науковці визначають як сукупність корисних для суспільства стійких форм повсякденної поведінки в побуті, спілкуванні, різних видах 
діяльності. Культура поведінки не зводиться до формального додержання етикету. Вона тісно пов'язана з моральними почуттями і уявленнями та підкріплює їх [6, с. 27].

Виходячи із аналізу розроблених підходів до розуміння культури поведінки дітей, зазначимо, що під культурою поведінки дітей 6 - 7-го років життя варто розуміти сукупність способів самоорганізації їхньої діяльності відповідно до морально-естетичних вимог суспільства шляхом зіставлення власних «етичних інстанцій» із соціальними очікуваннями рідних, старших, однолітків.

М. Федорова у структурі поняття культура поведінки дітей 6 -7-го років життя виокремлює емоційно-почуттєвий, ціннісно-мотиваційний, когнітивний i праксичний компоненти [6].

Емочійно-почуттєвий компонент культури поведінки передбачає розвиток емоційної сприйнятливості; сформованість естетичних, моральних почуттів (провини, сорому, совісті, відповідальності); здатність до емпатії; наявність емоційно-позитивного ставлення зразків поведінки, довкілля, людей, себе.

Виховання культури поведінки передбачає формування емоційно-позитивного ставлення до себе, оточуючих людей, зразків поведінки, довкілля відповідно до цінностей, ідеалів суспільства. Особливістю формування ставлення до себе у дошкільника та першокласника шестирічного віку є те, що воно повністю відображає оцінні судження дорослих [6].

Когнітивний компонент культури поведінки передбачає розвиток самосвідомості особистості; формування соціальних понять, оцінних еталонів; наявність знань про норми культурної та безпечної поведінки й усвідомлення доцільності їх дотримання; наявність елементарних уявлень і знань про людей, про навколишній світ і формування на основі цих знань морально-естетичних ідеалів, цінностей, зразків поведінки. Формування знань про норми поведінки, формування соціальних понять, оцінних еталонів, розвиток Яконцепції сприяють втіленню моральної свідомості в поведінку дитини [6].

Мотиваційно-ціннісний компонент культури поведінки передбачає наявність у дитини ціннісних орієнтацій, що відповідають вищим потребам особистості, соціуму; формування внутрішньої мотивації поведінки; розвиток мотивів обов'язку, а також мотивів самолюбності i самоствердження, ігрових, змагальних, моральних та пізнавальних мотивів. У психологічній науці обгрунтовано, що основу мотиваційної сфери особистості становлять потреби, що обумовлені рівнем соціокультурного розвитку суспільства (Б. Ломов, С. Рубінштейн). М. Федорова на основі аналізу психологічних досліджень Л. Божович, М. Матюхіної пропонує відповідну ієрархію мотивів старших дошкільників: широкі суспільні мотиви (самоствердження, самовдосконалення, прагнення зробити приємне оточуючим); вузькоособисті мотиви (добробут, престижу), серед яких перемагає мотив «хочу отримувати хороші оцінки»; пізнавальні мотиви, пов'язані 3 інтересом до процесу і змісту навчання; негативні мотиви. 3 усіх мотивів дитиною визначаються провідні, найбільш значущі для досягнення успіху, які підпорядковують другорядні мотиви. Завдяки цьому старший дошкільник стає здатним до морального вибору [6].

Праксичний компонент культури поведінки передбачає формування довільної поведінки; розвиток саморегуляції поведінки; формування у дитини умінь, навичок та звичок культурної поведінки; формування умінь виявляти негативні емоції соціальними засобами та відсутність проявів деструктивної агресії у поведінці. Саме усвідомлене оволодіння окремими зовнішніми формами соціальних норм; готовність дитини до сприймання правил поведінки та тих iii зразків, що демонструє дорослий сприяє формуванню довільності поведінки дитини, ії моральної саморегуляції, що виявляються у здатності узгоджувати власну поведінку 3 кращими зразками поведінки однолітків шляхом самопорівняння та у здатності корегувати ії̈ з метою пошуку, адекватної за даних умов [6].

Аналіз змісту Базової програми розвитку дитини «Я у світі» дозволяє виокремити основні критерії сформованості культури поведінки дітей старшого дошкільного віку, а 
саме: культура діяльності (навчальна, трудова, ігрова); культура спілкування (культура мовлення, спілкування 3 дорослими, спілкування 3 однолітками); культура побуту (культура зовнішнього вигляду, гігієнічні навички, самообслуговування) [1].

Культура спілкування передбачає виконання дитиною норм і правил спілкування 3 дорослими, однолітками, заснованих на повазі й доброзичливості, а також чемну поведінку в громадських місцях, побуті. Культура спілкування передбачає вміння не тільки діяти так, як треба, але й стримуватися від непотрібних у даних обставинах дій, слів, жестів. Культура спілкування обов'язково передбачає культуру мовлення, наявність у дошкільника достатнього запасу слів, уміння говорити.

Культурно-гігієнічні навички - важливий складник культури поведінки. Охайність, додержання в чистоті рук, тіла, одягу, взуття продиктована не тільки вимогами гігієни, але й нормами взаємин [1, с. 17].

Оперативне реагування на ситуативні негативні прояви поведінки дітей на основі розуміння їх природи та знання чинників.

Проаналізувавши психолого-педагогічну літературу, ми встановили, що до найбільш поширених ситуативних негативних проявів, які спостерігаються у старшому дошкільному віці можна віднести наступні: істерики, страхи, неслухняність, нечесність, жадібність, замкнутість, сором'язливість, кожен з яких має певні особливості прояву. Розуміння природи та знання чинників таких ситуативних негативних проявів $є$ важливим аспектом у їх попередженні $[4 ; 5 ; 7 ; 8]$.

Подамо узагальнені характеристики найбільш поширені негативні прояви у поведінці старших дошкільників та чинники, що їх зумовлюють.

Чинниками істерик є: кризи психо-вікового розвитку дитини, іï нервова перевтома, неправильна позиція дорослих у вихованні (задоволення усіх бажань дитини, непослідовність лінії виховання тощо), патологія розвитку психіки дитини, захворювання центральної нервової системи.

Чинники, що породжують страхи: наслідування дорослих; психічна травма чи пережите емоційне потрясіння; ускладнена адаптація до закладу освіти, нового колективу; ірраціоналізація дитячого мислення; почуття самотності; необхідність взаємодії з новим і незнайомим.

Серед чинників, що можуть зумовлювати дитячі крадіжки, науковці виокремлюють такі: надмірна вимогливість з боку дорослих; ігнорування дорослим дитячих потреб; прагнення дитини привернути до себе увагу дорослих.

Нечесність у дитини виникає під впливом таких чинників: уникнення покарання (пов'язане 3 неправильною позицією батьків: покарати, не розібравшись із чинниками): страх, приниження; нечесність заради спасіння; нечесність та хвастливість.

Чинники жадібності: особливості вікового самоусвідомлення дитини, недосконалість форм відстоювання дитиною власних інтересів, неправильна позиція дорослих щодо дитячих речей та іграшок.

Замкнутість та сором'язливість можуть виникати 3 різних причин: емоційної депривації внаслідок тривалого перебування в лікарні без батьків та інших близьких людей, переживання дитиною почуття власної небажаності, холодного чи байдужого ставлення до неї з боку батьків; індивідуальні патологічні особливості емоційної сфери; замкнутість як вияв важкого психічного розладу - аутизму; несформованість психічних механізмів соціальної перцепції - ідентифікації, емпатії, рефлексії; несформованість комунікативних умінь, соціальна некомпетентність - невміння поводитися в колективі.

Дотримання відповідної стратегії виховання дитини, яка схильна до ситуативних негативних проявів у поведіниі.

Виокремлення й розроблення стратегій виховання дитини, їх особливостей і ефективного застосування перебуває у тісному зв'язку з індивідуальною позицією дорослого у вихованні. У дошкільному віці діти проходять значний шлях свого розвитку- і головна роль у цьому належить оточуючим, насамперед сім”ї, батькам [3, с. 97]. 
Науковці визначають чинники виховання і стилі спілкування дорослих, що сприяють формуванню негативних емоційних станів дітей:

- суперечливість вимог до дитини з боку батьків, унаслідок чого в дитини формується опозиційне ставлення до зовнішнього оточення;

- власні часті негативні емоційні стани і відсутність навичок контролю й саморегуляції;

- використання покарання дітей як засобу реагування й розрядки дорослими власних негативних емоцій;

- негативний стиль спілкування 3 дитиною;

- використання наказів, звинувачень і погроз;

- вербальна образа дітей;

- ігнорування почуттів та інтересів дитини [3, с. 88-89].

На думку В. Білоусової, застосування виховних стратегій з дітьми, що мають негативні прояви у поведінки, має грунтуватись на відповідних організаційно-педагогічних позиціях:

1. Відокремлення дорослим власних почуттів і дій.

2. Адекватне реагування на почуття дитини. Сприяння конструктивному звільненню власних негативних емоцій ( через слова, а не діï).

3. Забезпечення самостійності й активності дитини у виборі власного покарання.

4. Обмеження на небезпечні та руйнівні дії. Допомога дитині у спрямуванні власної активності в дозволене русло.

5. Научіння дитини нормам і правилам поведінки в різних місцях і різних життєвих ситуаціях - ненав'язливо та без моралізування.

6. Демонстрація власного прикладу культурного поводження 3 іншими людьми, предметами та в довкіллі [2].

Отже, у роботі з дітьми, схильними до ситуативних негативних проявів, слід дотримуватись відповідної стратегії у вихованні. Чітко спланована стратегія дій, що враховує особливості дітей, значно впливає на процес виховання дітей, на чинники виникнення негативних проявів у їх поведінці, можливостей перевиховання.

3 метою емпіричного вивчення особливостей попередження ситуативних негативних проявів у поведінці дошкільників, нами проведене експериментальне дослідження, що дозволило розв'язати такі дослідницькі завдання: практично вивчити сформованість культури поведінки дошкільників; виявити можливості оперативного втручання дорослих у відповідь на ситуативні негативні прояви поведінки дитини на основі розуміння їх природи та знання чинників детермінації; визначити домінуючі стратегії виховання дітей зі стійкими негативними проявами поведінки в сім'ї.

Сформованість культури поведінки дошкільників як превентивної основи попередження негативних проявів у їхній поведінці досліджувалась за допомогою методу спостереження як основного та методу бесіди як допоміжного. Їх мета: визначення сформованості культури поведінки дошкільників на основі відповідних показників в емоційній, ціннісно-мотиваційній, когнітивній, праксичній сферах.

Оперативне реагування на ситуативні негативні прояви на основі розуміння їх природи та знання чинників детермінації досліджувалась за допомогою методу спостереження, як основного методу та інтерв'ювання батьків як допоміжного. Їх мета: визначення особливостей оперативного реагування дорослих у відповідь на ситуативні негативні прояви. Особливості відслідковувалися за відповідним алгоритмом: негативні прояви, їх можливі чинники, доцільна тактика припинення такої поведінки.

Визначення домінуючої стратегії виховання дитини з постійними негативними проявами у поведінці досліджувалась за допомогою методу анкетування вихователів. Анкета складалася $з$ трьох блоків. В сукупності запитання анкети надавали можливість чітко окреслити загальну стратегію виховання дітей зі стійкими негативними проявами та використовувати їі у повсякденному житті. 
Педагогічний експеримент здійснювався на базі ДНЗ № 9 Центру екологічного виховання «Лілея» м. Ніжина.

Унаслідок проведеної дослідно-експерементальної роботи встановлено, що формування культури поведінки, на думку вихователів і батьків дітей дошкільного віку, $є$ одним із основних шляхів попередження негативних проявів у поведінці дошкільників (100\% опитаних). Вихователі щодо формування культури поведінки дітей застосовують такі форми й методи роботи: бесіди на моральну тематику, пояснення, ігри на формування знань про правила культурної та безпечної поведінки, заняття на розвиток прагнення діяти відповідно до соціально схвалюваних норм і вимог та надають перевагу практичним методам. Однією 3 головних умов ефективного впливу на дитину, на думку вихователів, є співпраця з батьками, проте така робота, на жаль, проводиться несистематично, оскільки батьки відмовляються, спираючись на брак часу.

Сформуваність культури поведінки старших дошкільників під час різних видів діяльності визначалась за такими показниками: в емоційній сфері: сформованість моральних почуттів відповідальності (51\%), здатність до емпатії, що виражалось у співчутті, переживанні за однолітків (39\%), емоційно-позитивне ставлення до зразків поведінки (52 \%); у изіннісно-мотиваційній сфері: прагнення діяти відповідно до соціально схвалюваних норм та вимог (41\%), сформованість ігрових мотивів, що виражалось у прагненні реалізувати свої потреби та бажання за допомогою гри (70\%); у когнітивній cpepi: наявність знань про правила культурної та безпечної поведінки, що яскраво виявлялось під час режимних моментів (40\%), усвідомлення доцільності дотримання правил поведінки (30\%); у праксичній сфері: сформованість у дитини умінь, навичок та звичок культурної поведінки (41%), становлення елементарної саморегуляції поведінки $(51 \%)$

Отже, сформованість культури поведінки дітей перебуває на середньому рівні.

Стосовно виявлення ситуативних негативних проявів поведінки та чинників, що їх зумовлюють, ми виокремили низку найбільш поширених негативних проявів: жадібність, жорстокість, дитячі скарги, агресія, нечесність. На основі проведеного спостереження, бесіди з батьками та інтерв'ювання вихователів ми можемо окреслити такі чинники їх виникнення: недоліки сімейного виховання, прагнення уникнути покарання, несформованість комунікативних умінь, соціальна некомпетентність, недостатність розвитку афективно-вольових сторін характеру, прагнення привернути до себе увагу тощо.

За результатами проведеного інтерв’ювання батьків щодо поширеності негативних проявів та чинників, що їх зумовлюють в сімейному оточенні, ми встановили, що окрім вище зазначених, досить часто батьки стикаються з істериками, неслухняністю, страхами, замкнутістю, сором'язливістю (у 80 \% дітей). За оцінкою батьків і педагогів, вони можуть бути зумовлені такими чинниками: нервовою перевтомою дитини, почуттям самотності, непослідовністю лінії виховання в сім'ї, відсутністю у дорослих власних стійких моральних позицій, незнанням і нерозумінням батьками внутрішнього світу власної дитини, обмеженням дитячої самостійності.

Нами були виявлені типові реакції батьків на ситуативні негативні прояви поведінки дітей: батьки переважно погоджуються із будь-якими вимогами дитини; іноді наполягають на своєму; батьки не зважають на слова й прохання власної дитини; батьки починають обурюватися; байдуже віддають дитину вихователю. Тож можна вважати, що всі ці аспекти негативно впливають на дитину i, як наслідок, сприяють виникненню відхилення в її поведінці.

Щодо визначення стратегії виховання дитини з постійними негативними проявами, ми з'ясували, що майже всі вихователі по-різному розуміють поняття «негативні прояви у поведінці», характеризуючи їх як прояви агресії, впертості, як вередливість, неслухняність. 
Вихователі зазначили, що, працюючи в ДНЗ, доволі часто стикаються 3 негативними проявами поведінки дітей, зумовленими кризами психовікового розвитку - $50 \%$ опитаних; негативними проявами поведінки, зумовленими неправильним вихованням 75 \% опитаних; негативними проявами поведінки, зумовленими дефіцитом уваги - 25 \% і $25 \%$ вихователів стикаються 3 негативними проявами поведінки, зумовленими адаптацією дитини до ДНЗ.

Респонденти зауважили, що в кожній групі є діти, схильні до негативних проявів поведінки і найчастіше такі прояви зумовлені кризами психовікового розвитку та неправильним вихованням (75\%). Вихователі вважають за доцільне проведення психолого-педагогічної профілактики негативних проявів поведінки вже в дошкільному віці і кожен проводить її у своїй групі.

Серед реалізованих заходів первинної профілактики переважна більшість вихователів назвали заходи, спрямовані на формування моральних понять, пов'язаних із почуттями бережливого ставлення до себе, відповідальності за власні вчинки; виховання уявлень дітей щодо позитивного та негативного досвіду людської поведінки стосовно самої себе та інших людей; усвідомлення себе частиною природи, розуміння власних можливостей.

3-поміж завдань вторинної профілактики педагоги вказали на необхідність визначення найбільш чутливих, сензитивних до виховного впливу компонентів у структурі особистості дитини (рис характеру, особливостей темпераменту, інтересів тощо); 75 \% вказали на вивчення умов і чинників виникнення схильності особистості до негативних проявів поведінки і 75 \% наголосили на проведенні діагностики мотивів такої поведінки дітей. Найпоширенішими методами діагностики вказали: знайомство із сім'єю, вивчення їі соціально-психологічного клімату та спостереження за поведінкою дитини на занятті та під час ігрової діяльності, методи вивчення стану здоров'я дітей.

Тож, ми 3'ясували, що вихователі ДНЗ проводять роботу щодо профілактики негативних проявів поведінки дошкільників, вважають свою роботу по запобіганню негативних проявів поведінки дошкільників не досить результативною, оскільки профілактична робота в більшості випадків здійснюється практично без допомоги та участі батьків. $60 \%$ батьків не приділяють належної уваги формуванню культури поведінки власних дітей.

У публікації окреслено, проаналізовано та практично вивчено особливості попередження ситуативних негативних проявів у поведінці дітей, а саме: формування культури поведінки дитини; оперативного реагування на ситуативні негативні прояви; педагогічно доцільної стратегії у вихованні дітей із негативними поведінковими проявами.

\section{Література}

1. Базова програма розвитку дитини дошкільного віку «Я у світі» / [наук. ред. та упор. О. Л. Кононко]. - 3-те вид., випр. - К. : Світич, 2009. - 430 с. 2. Білоусова В. О. Виховання культури поведінки дітей / В. О. Білоусова - К. : Радянська школа, 1986. - 160 с. 3. Медведєв Т. П. Все починається в сім'ї / Т.П. Медведєв, А.В.Над'ярний. - К. : Молодь, 1983. - 104 с. 4. Оржеховська В. М. Профілактика девіантної поведінки неповнолітніх: [навч. посіб.]. / В.М. Оржеховська, Т.Є. Федорченко. - Черкаси, 2008. - 376 с. 5. Пихтіна Н. П. Профілактика негативних проявів у поведінці дітей. Тексти лекцій. / Н.П. Пихтіна. - Ніжин, 2012. - 65 с. 6. Федорова М. А. Виховання культури поведінки у дітей 6-7-го років життя (в умовах навчальновиховного комплексу «школа - дитячий садок») : дис... на здобуття наук. ступеня канд. пед. наук: спец. : 13.00.07 «Теорія і методика виховання» / Федорова Марія Анатоліївна. - К., 2005. - 237 с. 7. Федорченко Т. Є. Рання профілактика негативних проявів у поведінці дітей : [навч.-метод. посіб.] / Т. С. Федорченко. - К. : Тов. «ХІК», 2003. - 128 с. 8. Федорченко Т. Є. Рання профілактика девіантної поведінки молодших школярів : [навч.-метод. посіб.] / Т. С. Федорченко, О. В. Потапова. Запоріжжя : ПП «АА Тандем», 2008. - 236 с. 